\title{
Permasalahan Hidrologi di Daerah Aliran Sungai Kampar: Suatu Telaah Multi Perspektif
}

\author{
Mohd. Yunus ${ }^{1 *}$ \\ ${ }^{1}$ Perkumpulan Alam Zamrud, Kabupaten Kampar - Provinsi Riau
}

\section{Abstrak}

Kata Kunci: daerah Persepsi para pihak merupakan elemen kunci untuk mewujudkan aliran sungai; para pengelolaan DAS Kampar yang berkelanjutan. Kajian ini memiliki tujuan pihak; persepsi mengidentifikasi permasalahan hidrologi berdasarkan persepsi para pihak dan mengidentifikasi kesenjangan antara persepsi tersebut. Kajian ini telah dilaksanakan pada bulan September 2018 - April 2019 di Provinsi Riau dan Provinsi Sumatera Barat. Metode analisis yang digunakan adalah analisis deskriptif, meliputi proses editing data, kategorisasi, dan penafsiran data. Permasalahan hidrologi yang selama ini sering terjadi menurut masyarakat adalah pencemaran, banjir, erosi, abrasi, kekeruhan, dan pendangkalan. Faktor penyebab permasalahan hidrologi meliputi penggunaan pelet dari keramba jaring apung (KJA), limbah kelapa sawit, dan pembukaan lahan yang masif, penebangan liar di bagian hulu dan penambangan batu sungai. Persepsi umum dari pemerintah menegaskan bahwa dalam beberapa tahun terakhir ini, kualitas air Sungai Kampar semakin memburuk. Hal tersebut disebabkan oleh beberapa hal, meliputi maraknya penebangan hutan, pembangunan yang bersifat parsial dan sektoral, belum tersedianya perencanaan pengembangan sumber-sumber air yang menyeluruh dan terpadu yang mencakup aspek pemanfaatan, pengelolaan, serta pengendalian dan pelestarian. Secara umum, persepsi para pihak memiliki persamaan. Walaupun begitu, masih terdapat beberapa perbedaan.
\end{abstract}

Keywords: watershed;
stakeholders;
perception

\section{Abstract}

The perception of stakeholders is a key element in realizing sustainable management of the Kampar watershed. This study has objectives, namely identifying hydrological problems based on the perceptions of the parties and identifying the gaps between these perceptions. This study was conducted in September 2018 - April 2019 in Riau Province and West Sumatra Province. The analytical method used is descriptive analysis, which includes the process of editing data, categorizing, and interpreting data. Hydrological problems that often occur according to the community are pollution, flooding, erosion, abrasion, turbidity, and silting up. Factors causing hydrological problems include the use of pellets from floating net cages, palm oil waste, and massive land clearing, illegal logging upstream and river rock mining. The general perception of the government confirms

\footnotetext{
*Penulis koresponden: mohd.yoenoes@gmail.com
} 
that in recent years, the water quality of the Kampar River has deteriorated. This is caused by several things, including the deforestation, partial and sectoral development, the unavailability of a comprehensive and integrated water resources development plan that includes aspects of utilization, management, and control and preservation. In general, the perception of the parties has similarities. Even so, there are still some differences.

\section{PENDAHULUAN}

Sungai Kampar merupakan salah satu sungai besar di Pulau Sumatera. Secara administrasi, Sungai Kampar berada di dua provinsi, bagian hulu sungai Kampar terletak di Kabupaten Lima Puluh Koto, Pasaman dan Sawahlunto di Provinsi Sumatera Barat, sedangkan bagian tengah wilayah sungai hingga muara terletak di Provinsi Riau. Sungai Kampar memiliki dua anak sungai, yaitu sungai Kampar Kanan dan sungai Kampar Kiri, bertemu di Langgam, Kabupaten Pelalawan. Sungai ini memiliki panjang $\pm 580 \mathrm{~km}$ dengan luas daerah aliran sungai (DAS) $\pm 24.586 \mathrm{~km} 2$ (Kementerian Pekerjaan Umum dan Perumahan Rakyat, 2015).

DAS Kampar telah memberikan pengaruh yang sangat signifikan terhadap kehidupan masyarakat di sepanjang alirannya. DAS Kampar tidak saja berarti dalam dimensi fisik, tetapi juga menjadi media interaksi sosial budaya, maka tidak heran jika Asnan (2019) menyebutkan bahwa keberadaan sungai ini sebagai salah satu faktor sejarah pulau Sumatera.

DAS Kampar memiliki beragam manfaat yang telah dinikmati oleh \pm 3 juta penduduk (WWF Indonesia, 2018). Keragaman komponen ekosistem dan keragaman interaksi yang ada di dalamnya menyebabkan pengelolaan DAS Kampar harus melibatkan banyak pihak. Proses ini bukanlah sesuatu yang mudah, sebagaimana dinyatakan oleh Lee, et al (2018) bahwa para pihak yang berbeda dapat mempunyai perspektif yang berbeda akan fungsi DAS dan memungkinkan adanya kesenjangan pengetahuan ekologi. Penulis beranggapan bahwa persepsi para pihak merupakan elemen kunci untuk mewujudkan pengelolaan DAS Kampar yang berkelanjutan, inilah yang menjadi tinjauan utama sekaligus ciri khas artikel ini.

$$
\text { Kajian ini memiliki tujuan }
$$
mengidentifikasi permasalahan hidrologi Sungai Kampar berdasarkan persepsi para pihak, yaitu masyarakat, pemerintah, dan akademisi dan mengidentifikasi kesenjangan antara ketiga persepsi tersebut dan menganalisa secara terpadu guna mendapatkan gambaran permasalahan hidrologi Sungai Kampar.

\section{METODE PENELITIAN}

Kajian ini telah dilaksanakan pada bulan September 2018 - April 2019 di Provinsi Riau, yaitu di Kabupaten Kampar serta di Provinsi Sumatera Barat, yaitu di Kabupaten Lima Puluh Kota. Lokasi ini dipilih karena merupakan daerah tangkapan air bagi sungai Kampar.

Bahan dan alat yang digunakan dalam kajian ini adalah kuesioner (pedoman wawancara), alat tulis, perekam suara, dan kamera. Jenis data yang digunakan dalam kajian ini terdiri dari data primer dan data sekunder. Data primer bersumber dari hasil survei dan hasil penjajakan dengan kuesioner kepada responden terpilih dan dari kalangan pembuat kebijakan. Sementara itu, data sekunder diperoleh dari berbagai instansi terkait. Persepsi para pihak yang dianalisis dalam kajian ini berasal dari 3 (tiga) kelompok, yaitu persepsi masyarakat, pemerintah, dan akademisi.

Para pihak yang dimaksud adalah mereka yang memiliki peran secara langsung maupun tidak langsung terhadap DAS Kampar. Metode analisis yang digunakan adalah analisis deskriptif, meliputi proses editing data, kategorisasi, dan penafsiran data (Miles \& Banyard, 2007).

\section{HASIL DAN PEMBAHASAN}

Lokasi kajian memiliki karakteristik masing-masing yang khas, terdapat perbedaan namun terdapat pula persamaan. Jika dilihat dari sisi mata pencaharian masyarakat, pemanfaatan sumber daya alam secara langsung masih sangat dominan, seperti nelayan, petani, pertambangan, dan peternak. Hal ini mengindikasikan bahwa sebagian besar 
masyarakat memiliki interaksi dan ketergantungan kepada sumber daya alam, yaitu sungai, lahan, dan hutan.

Masyarakat yang berprofesi sebagai nelayan banyak ditemui di Kecamatan XIII Koto Kampar, Kabupaten Kampar karena daerah ini dikelilingi oleh waduk/genangan PLTA Koto Panjang, sehingga ketersediaan habitat ikan juga melimpah. Sementara masyarakat yang berprofesi sebagai petani ditemui hampir pada semua lokasi kajian, walaupun dengan komoditas yang berbeda.

Penggunaan lahan didominasi oleh pertanian, khususnya perkebunan, seperti sawit, karet, kelapa, dan gambir. Perkebunan sawit banyak ditemui di bagian Provinsi Riau, sementara gambir banyak ditemui di bagian Provinsi Sumatera Barat. Aktivitas penggunaan lahan yang intensif juga didukung oleh aksesibilitas yang bagus dan merata, hanya di Kecamatan Kapur IX, Kabupaten Lima Puluh Kota yang masih sulit diakses.

Ketergantungan yang tinggi terhadap sungai hanya ditemui di Kecamatan XIII Koto Kampar, Lima Puluh Kota, dimana hampir $35 \%$ masyarakatnya berprofesi sebagai nelayan. Kuantitas dan kualitas air sungai tentu menjadi faktor penting untuk keberlanjutan hidup masyarakat di daerah ini. Hal yang sedikit berbeda ditemui di daerah lain, dimana pemanfaatan sungai hanya sebatas pada keperluan domestik dan irigasi.

Permasalahan hidrologi yang selama ini sering terjadi menurut persepsi masyarakat adalah pencemaran, banjir, erosi, abrasi, kekeruhan, dan pendangkalan. Faktor penyebab permasalahan hidrologi di bagian Provinsi Riau meliputi sisa pakan ikan dari Keramba Jaring Apung (KJA), limbah kelapa sawit, dan pembukaan lahan yang masif. Sementara itu, faktor penyebab di bagian Provinsi Sumatera Barat didominasi oleh penebangan liar dan penambangan batu sungai.

Pada umumnya, masyarakat sudah mengetahui bahwa berkurangnya tutupan hutan akan menyebabkan terjadinya banjir, selain karena curah hujan yang tinggi. Namun, sebagian masyarakat yang lain juga menyatakan bahwa peristiwa banjir ini secara alami memang sudah seringkali terjadi sejak sebelum maraknya penebangan liar. Banjir umumnya terjadi sekali dalam setahun, biasanya pada bulan Oktober sampai Desember.
Tipe banjir yang terjadi di daerah hulu adalah banjir bandang, berupa aliran air yang sangat besar dan datang secara tiba-tiba, namun tidak berlangsung lama (Mulyanto et al, 2012). Selain itu, pada wilayah tertentu di Nagari Durian Tinggi mengalami banjir karena merupakan bagian yang terendah dari wilayah sekitar, tidak mampu menampung air hujan dalam waktu yang cepat dengan volume tinggi. Menurut warga setempat, adalah normal jika debit sungai bertambah besar pada musim hujan, karena ada bagian air hujan yang masuk ke sungai. Istilah "banjir" dimaksudkan sebagai peningkatan debit sungai sehingga permukaan air sungai naik beberapa meter dibanding biasanya (kondisi normal), namun tidak sampai meluap ke luar badan sungai (Zevenbergen et al, 2020). Pada saat "banjir" tersebut, air sungai lebih keruh dari biasanya.

Longsor yang terjadi menurut masyarakat terdiri dari beberapa tipe, yaitu longsor di kawasan pemukiman, longsor (tebing) jalan, longsor (tebing) sungai, longsor di kawasan budidaya pertanian, dan longsor di kawasan hutan. Longsor disebabkan oleh hujan deras yang menggerus dan meruntuhkan material tanah pada tebing sangat curam. Kejadian longsor dihubungkan dengan air yang berlebihan, baik dari hujan maupun aliran deras (permukaan dan sungai) (Yilmaz \& Ercanoglu, 2019).

Kejadian longsor berkorelasi dengan tutupan lahan, tempat dimana air hujan diserap atau dilepaskan (Sahin et al, 2020). Tutupan lahan yang mendominasi di bagian hulu Sungai Kampar adalah perkebunan gambir yang ditanam di lahan miring. Cara bertanam seperti ini dipilih masyarakat karena lebih mudah dalam pemanenan, karena tajuk tanaman berada di sebelah atas sehingga tidak bersentuhan langsung dengan tajuk tanaman bagian sebelah bawah. Selain itu, hal ini juga untuk menghindari air tergenang, karena tanaman gambir tidak tahan terhadap genangan air (Dhalimi, 2015).

Kejadian erosi dapat dilihat dari dua sudut, pertama dari aspek kehilangan tanah lahan dan kedua dari aspek pengendapan material tanah yang terangkut oleh aliran air (sedimen) (Jia et al, 2020). Masyarakat di wilayah kajian tidak melihat adanya masalah erosi yang terkait dengan sedimentasi, karena di sepanjang sungai tidak dijumpai adanya pengendapan lumpur kecuali batu-batuan. Terkait dengan erosi, yang dapat dirasakan 
oleh masyarakat adalah kekeruhan air sungai yang berdampak terhadap kebutuhan domestik.

Indikasi pencemaran air sungai ditemui di bagian Provinsi Riau, karena banyaknya kegiatan yang berhubungan langsung dengan sungai Kampar, antara lain kegiatan industri, perkebunan, kehutanan, kegiatan nelayan, penambangan, dan kegiatan domestik.

Persepsi umum dari pemerintah menegaskan bahwa dalam beberapa tahun terakhir ini, kualitas air Sungai Kampar semakin memburuk. Hal tersebut disebabkan oleh beberapa hal, meliputi maraknya penebangan hutan, pembangunan yang bersifat parsial dan sektoral, belum tersedianya perencanaan pengembangan sumber-sumber air yang menyeluruh dan terpadu yang mencakup aspek pemanfaatan, pengelolaan, serta pengendalian dan pelestarian.

Pihak pemerintah menitikberatkan penyebab kerusakan DAS Kampar merupakan akibat dari penggunaan lahan yang tidak sesuai, dan konversi penggunaan lahan sebagai tanggapan terhadap tekanan sosial - ekonomi yang sulit dicegah, sehingga melampaui daya dukung nya. Penebangan yang tidak terkendali mengakibatkan penggundulan hutan di bagian hulu. Erosi dan sedimentasi di anak sungai, sungai, dan waduk merupakan akibat langsung, dan juga banjir adalah dampak tidak langsung dari kegiatan tersebut.

Pada sisi yang lain, pemerintah juga menyoroti tekanan penduduk terhadap kawasan hutan yang semakin meningkat seiring dengan peningkatan pertumbuhan penduduk, mengakibatkan kebutuhan akan lahan juga semakin meningkat. Keadaan ini memicu pembukaan lahan untuk keperluan tanaman yang secara ekonomi merupakan jenis yang cepat menghasilkan. Kawasan hutan kritis ini sebagian besar secara fisik telah dikuasai oleh sebagian besar peladang berpindah/perambah, bahkan sebagian telah di klaim sebagai tanah suku/adat/milik nenek moyang.

Badan Pengelolaan Daerah Aliran Sungai dan Hutan Lindung (BPDASHL) Indragiri Rokan telah melaksanakan kajian evaluasi daya dukung DAS Kampar pada tahun 2015. Kajian ini berupa penilaian pada semua parameter lahan, tata air, sosial ekonomi, investasi bangunan air dan pemanfaatan ruang wilayah.

Hasil kajian menunjukkan bahwa nilai evaluasi daya dukung DAS Kampar sebesar 111.00, jika merujuk pada Peraturan Menteri
Kehutanan Nomor 61 Tahun 2014 tentang Monitoring dan Evaluasi Pengelolaan Daerah Aliran Sungai, maka nilai ini termasuk dalam kategori buruk.

Kondisi daya dukung DAS Kampar dipengaruhi oleh beberapa faktor, diantaranya adalah faktor lahan. Persentase lahan kritis pada DAS Kampar memiliki skor yang besar, termasuk dalam kriteria sangat tinggi, begitu juga dengan indeks erosi yang termasuk sangat tinggi. Selain kondisi lahan, kondisi tata air juga memberikan pengaruh yang cukup besar, seperti muatan sedimen dan kejadian banjir. Selain hal tersebut, keberadaan bangunan vital seperti bendungan PLTA dan daerah irigasi memberikan dampak yang sangat bermanfaat bagi kehidupan, mengingat tingginya nilai investasi bangunan air sehingga perlu dijaga agar tetap berfungsi dengan baik.

Dinas Lingkungan Hidup dan Kehutanan (DLHK) Provinsi Riau telah melakukan evaluasi kualitas Sungai Kampar, dari 2014 sampai 2018. Mayoritas titik pantau mengindikasikan bahwa Sungai Kampar berada dalam kondisi tercemar berat. Parameter dominan penyebab penurunan kualitas air Sungai Kampar di beberapa titik pantau adalah Dissolved Oxygen (DO), BOD, COD, klorin bebas, fecal coli dan total fosfat. Di beberapa titik pantau lain dominan parameter TSS, besi dan total coliform. Sumber pencemaran itu dari aktivitas domestik, industri, peternakan, perkebunan, pertanian, hutan tanaman industri, perikanan dan pertambangan.

Evaluasi ini menyatakan, limbah domestik jadi sumber utama pencemaran Sungai Kampar, selain industri, perkebunan dan pertanian. Pihak DLHK Provinsi Riau menyatakan bahwa sampai saat ini pengawasan berkelanjutan hanya dilaksanakan untuk kegiatan industri, belum menyentuh pembuangan limbah dari rumah tangga.

Pusat Pengendalian Pembangunan Ekoregion Sumatera (P3ES) juga telah melaksanakan kajian daya tampung beban pencemaran Sungai Kampar pada tahun 2014. Kajian ini membagi Sungai Kampar jadi lima wilayah dan menetapkan beberapa titik pantau. Parameter yang diukur, BOD, COD dan TSS. Hasilnya, wilayah I, dari Muara Takus sampai Jorong Pertemuan, sepanjang 78,1 km, mengalami kelebihan beban pencemaran BOD 19,045 ton per hari. Beban pencemaran COD dan TSS masih di bawah baku mutu. Sebaliknya, wilayah II, dari Muara Sako 
sampai Rantau Berangin, sepanjang 175,4 km, beban pencemaran BOD dan COD di bawah baku mutu, sedang TSS melampaui daya tampung 143,396 ton per hari. Wilayah I dan II merupakan sumber bahan baku air minum.

Kondisi mengkhawatirkan terjadi di wilayah III, mulai Muara Sako hingga Sungai Subayang sepanjang 140,3 km. Beban pencemaran BOD melebihi daya tampung 170,108 ton per hari. Kelebihan beban pencemaran COD 108,764 ton per hari. Paling parah beban pencemaran TSS. Dengan daya tampung 358,292 ton per hari, beban pencemaran sampai $1.635,838$ ton per hari. Beban pencemaran BOD dan COD paling tinggi di Kecamatan Langgam, Pelalawan dan beban pencemaran TSS sama parahnya antara Kecamatan Kampar Kiri dan Kecamatan Langgam. Wilayah IV, dari Waduk Koto Panjang sampai Gunung Malintang, sepanjang $21,6 \mathrm{~km}$, sungai seperti wilayah I. Beban pencemaran dominan BOD yang melampaui daya tampung 6,759 ton per hari dan COD maupun TSS, di bawah baku mutu. Sumber pencemaran wilayah IV terutama berasal dari aktivitas manusia seperti penambangan emas tanpa izin pada anak-anak sungai di Kuantan Singingi.

Kondisi mengkhawatirkan juga terjadi di wilayah V, dari Teluk Meranti hingga Muara Sako, sepanjang 164,6 km. Kelebihan beban pencemaran BOD 580,819 ton per hari. Sedangkan kelebihan beban pencemaran COD 302,895 ton per hari. Kelebihan beban pencemaran TSS 297,725 ton per hari. Beban pencemaran BOD dan COD paling tinggi di Kecamatan Kuala Kampar. Sementara, beban pencemaran TSS tidak hanya di Kecamatan Kuala Kampar, juga di Kecamatan Langgam alias dari hulu dan hilir.

Sudah sejak lama sungai Kampar menarik minat para akademisi dari berbagai lembaga, keragaman komponen ekosistem serta kompleksitas di dalamnya merupakan daya tarik bagi para akademisi untuk melakukan riset dan pengembangan. Oleh karena itu, kami telah mengumpulkan persepsi akademisi dari berbagai institusi.

Akademisi dari Fakultas Teknik, Universitas Riau menyoroti perubahan tutupan lahan yang semakin masif di daerah tangkapan air waduk PLTA Koto Panjang. Mereka menyatakan bahwa dalam rentang 2011-2014, telah terjadi perubahan penggunaan lahan yang cukup signifikan, hutan lahan kering primer seluas $7.003,37$ ha $(2,21 \%)$, hutan lahan kering sekunder seluas $2.684,90$ ha $(0,85 \%)$, pertanian lahan kering bercampur semak seluas 1.132,68 ha $(0,36 \%)$. Berkurangnya luas penggunaan lahan tersebut menyebabkan meningkatnya penggunaan pertanian lahan kering seluas $7.325,53$ ha $(2,30 \%)$, tanah terbuka seluas $1.787,96$ ha $(0,56 \%)$, pemukiman seluas $1.005,80$ ha $(0,32 \%)$, sawah seluas 509,17 ha $(0,16 \%)$, dan perkebunan seluas 350,68 ha $(0,11 \%)$.

Pernyataan yang sama juga dilontarkan oleh akademisi dari Fakultas Perikanan dan Kelautan, Universitas Riau bahwa lahan yang berkurang dalam jumlah besar setiap tahunnya adalah lahan hutan yang dikonversi menjadi semak/belukar, pertanian lahan kering, dan perkebunan. Perubahan tipe penutupan lahan dari hutan menjadi perkebunan dan pertanian mengancam kelestarian daerah tangkapan air bagi waduk PLTA Koto Panjang. Fluktuasi debit air pada saat musim hujan dan musim kemarau di waduk PLTA Koto Panjang menjadi besar karena kemampuan vegetasi dalam melakukan infiltrasi air hujan menjadi berkurang. Sementara evaporasi pada saat musim kemarau semakin besar.

Aktivitas ekonomi masyarakat sebagian besar memiliki mata pencaharian sebagai petani pemilik pada lahan kering dengan jenis tanaman karet yang sudah lama diusahakan dan tanaman sawit yang menjadi alternatif pilihan sejak tahun 2004/2005 karena dianggap lebih menjanjikan. Untuk memenuhi kebutuhan minimal hidup layak (sektor pertanian/perkebunan kelapa sawit dan tanaman karet sebesar Rp. 1.122.000,- per bulan) masyarakat mulai mengonversi lahan hutan menjadi lahan perkebunan dan pertanian, karena lahan perkebunan yang ada dianggap sudah tidak dapat mencukupi lagi. Hal ini menyebabkan tekanan dan ketergantungan masyarakat terhadap lahan di daerah tangkapan air PLTA Koto Panjang semakin tinggi.

Pengusahaan tanaman karet saat ini bersifat monokultur, umumnya tidak diteras. Sejak tahun 2004/2005 masyarakat mulai mengonversi lahan karet dan pekarangan mereka menjadi tanaman kelapa sawit. Pola penggunaan lahan yang demikian apabila tidak dilakukan pengaturan dan pembatasan maka akan mengancam kelestarian daerah tangkapan air PLTA Koto Panjang, karena akan mengubah pola penutupan lahan, terutama komposisi vegetasi yang ada di dalam wilayah 
daerah tangkapan air. Pengelolaan kebun karet yang monokultur dan semakin banyaknya konversi lahan ke kebun kelapa sawit berdampak negatif terhadap kelestarian daerah tangkapan air PLTA Koto Panjang, terlebih lagi karena sifat tanaman kelapa sawit yang rakus akan air, sehingga akan mempercepat hilangnya air tanah di daerah tangkapan air pada saat musim kemarau.

Para akademisi ini juga menyoroti tingkat sedimentasi yang semakin tinggi di sungai Kampar yang mana hal tersebut telah berakibat pada terganggunya pasokan air untuk PLTA Koto Panjang. Sekelompok peneliti dari Fakultas Teknik, Universitas Riau telah melaksanakan sebuah kajian untuk menganalisis tingkat sedimentasi dan gerusan waduk PLTA Koto Panjang bagian hulu dengan menggunakan data penginderaan jauh. Mereka menggunakan berbagai skenario kondisi elevasi muka air. Hasil kajian memperlihatkan bahwa pada kondisi 1 (elevasi muka air rerata $76,67 \mathrm{~m}$ ) pada periode waktu dari tanggal 01 September 2000 sampai 11 Juli 2013 (12,87 tahun) telah terjadi sedimentasi dan gerusan berturut-turut sebesar 140,62 ha dan 97,47 ha, tingkat sedimentasi dan gerusan per tahunnya berturut-turut sebesar 10,95 ha/tahun dan 7,58 ha/tahun. Pada kondisi 2 (elevasi muka air rerata $77,73 \mathrm{~m}$ ) pada periode waktu dari tanggal 09 Desember 2001 sampai 16 Nopember 2013 (11,95 tahun) telah terjadi sedimentasi dan gerusan berturut-turut sebesar 146,23 ha dan 125,06 ha, tingkat sedimentasi dan gerusan per tahunnya berturut-turut sebesar 12,24 ha/tahun dan 10,47 ha/tahun. Pada kondisi 3 (elevasi muka air rerata $79,75 \mathrm{~m}$ ) pada periode waktu dari tanggal 09 Maret 2000 sampai tanggal 18 Desember $2013 \quad(13,79$ tahun) telah terjadi sedimentasi dan gerusan berturut-turut sebesar 325,69 ha dan 73,23 ha, tingkat sedimentasi dan gerusan per tahunnya berturut-turut sebesar 23,62 ha/tahun dan 5,31 ha/tahun.

Kelompok peneliti lainnya dari fakultas yang sama telah melakukan kajian untuk mengetahui pengaruh perubahan luasan hutan terhadap laju sedimen. Parameter perubahan luas hutan mempunyai pengaruh cukup dominan terhadap perubahan laju tahunan sedimen PLTA Koto Panjang. Pengurangan luas hutan sebesar $15 \%$ mempunyai pengaruh yang cukup sensitif terhadap volume perubahan laju sedimentasi tahunan yang masuk ke waduk PLTA Koto Panjang, hal ini ditandai peningkatan volume sedimen dari 1,4 juta $\mathrm{m}^{3}$ menjadi 11,4 juta $\mathrm{m}^{3}$ (peningkatan laju sedimen tahunan lebih dari 7 kali lipat).

Kualitas air Sungai Kampar yang semakin menurun juga mendapatkan perhatian dari para akademisi Universitas Riau. Mereka menyatakan bahwa limbah budidaya ikan yang berasal dari pakan telah kontribusi terhadap buangan limbah beban pencemaran air dari total-P sebanyak $53.611,9 \mathrm{~kg} /$ tahun $(0,0572$ $\mu \mathrm{g} / \mathrm{lt} / \mathrm{hari})$ atau sebanyak $13,46 \mathrm{kgP} /$ ton ikan yang diproduksi. Penurunan kualitas air terutama diakibatkan oleh berlimpahnya sisa pakan yang tidak termakan (35.540,5 $\mathrm{kgP} /$ tahun) dan berasal dari feses ikan (18.071,4 kgP/tahun).

Akademisi dari LIPI menyatakan bahwa Sub DAS sekitar Waduk Koto Panjang bagian utara dan bagian tengah cenderung mempunyai aliran permukaan, water yield dan potensi erosi yang lebih tinggi. Sungai bagian utara mempunyai luas yang lebih besar sehingga aliran debit harian dan sedimen yang masuk juga lebih banyak dari bagian sungai yang lain. Selain itu, tingginya potensi erosi di daerah ini dikarenakan berubahnya penggunaan lahan pada lokasi dengan kemiringan yang tinggi dan jenis tanah yang mempunyai erodibilitas tinggi juga.

Akademisi dari Universitas Muhammadiyah Sumatera Barat menyatakan bahwa penggunaan lahan kawasan DAS Mahat Hulu lebih didominasi oleh kebun gambir (Uncaria gambir Roxb) rakyat sejak 2 (dua) dasa warsa terakhir. Tanaman ini merupakan sumber mata pencaharian utama masyarakat sepanjang DAS di samping padi sawah. Akibat pertumbuhan penduduk dan keterbatasan lahan usaha menyebabkan hutan semakin mendapat tekanan untuk dialih fungsikan menjadi kebun. Pengelolaan lahan kebun belum dilakukan secara berteknologi (agroteknologi) sebagaimana teknologi konservasi yang dianjurkan, akibatnya terjadi erosi dan sedimentasi yang akhirnya DAS semakin kritis. Upaya untuk mempertahankan status kawasan hutan akan mendapat tantangan dari masyarakat setempat, karena mereka tidak memperoleh manfaat langsung dari upaya/kebijakan ini.

Terjadi kekurangan pasokan air untuk waduk PLTA Koto Panjang, terutama pada musim kemarau. Hal ini disebabkan oleh perubahan penggunaan lahan dari hutan menjadi areal penggunaan lain di kawasan hulu 
DAS. Akibat penggunaan lahan yang tidak rasional, erosi yang terjadi terus meningkat, kapasitas infiltrasi semakin menurun dan akibatnya volume aliran permukaan terus meningkat. Upaya melakukan rehabilitasi lahan dan pemberian pemahaman kepada petani hulu yang lebih berperan untuk menjaga lingkungan sudah dilakukan, namun hasil yang diharapkan belum terlihat secara nyata. Manfaat ekonomi sumber daya air DAS Mahat Hulu yang digunakan untuk pertanian lahan basah (sawah), PLTA, keramba jala apung, dan wisata, belum memberikan kontribusi (cost sharing) yang memadai untuk kegiatan rehabilitasi lahan.

Akademisi dari Universitas Andalas menyatakan bahwa indikasi degradasi hutan dan lahan tersebut telah lama terjadi di Sub DAS Mahat, yang ditandai dengan semakin memburuknya kondisi biofisik DAS seperti semakin meluasnya lahan kritis, meningkatnya nilai erodibilitas tanah, laju erosi telah melebihi nilai erosi yang dapat di toleransi (ETOL) serta nilai koefisien rezim sungai (KRS) yang semakin meningkat, sehingga daya dukung lingkungan sungai semakin menurun.

Fenomena turunnya debit sungai Batang Mahat sudah mulai terlihat sejak 10-15 tahun terakhir ini, hal ini merupakan masalah yang sangat serius karena merupakan ancaman bagi keberlanjutan fungsi PLTA Koto Panjang. Kondisi menurunnya debit ini diduga disebabkan oleh kondisi biofisik daerah tangkapan yang sudah terganggu, terutama dari segi resapan air hujan oleh lahan dan hutannya di kawasan hulu Sub DAS Mahat.

Secara umum, persepsi para pihak memiliki persamaan, misalnya terdapat persamaan persepsi bahwa tutupan lahan berpengaruh terhadap keberlangsungan DAS Kampar, perambahan hutan menyebabkan terjadinya bukaan lahan yang memicu erosi, sedimentasi, dan banjir. Persepsi yang sama juga terjadi terhadap kualitas air, dimana penurunan kualitas air di DAS Kampar menurut para pihak disebabkan oleh dua faktor utama. Faktor pertama adalah adanya erosi dan sedimentasi yang dihasilkan dari lahan-lahan terbuka di daerah hulu. Faktor kedua adalah adanya pencemaran dari berbagai macam kegiatan di sepanjang sungai dan anak sungai Kampar.

Walaupun begitu, masih terdapat beberapa perbedaan, misalnya terkait dengan program penanaman dan penghijauan yang sudah pernah dilakukan dan diprakarsai oleh pemerintah. Program tersebut menurut masyarakat tidak berjalan dengan baik dan tidak berkelanjutan. Namun, pihak pemerintah menyatakan bahwa program-program ini berhasil dan selalu dilaksanakan secara berkelanjutan.

Masing-masing pihak memiliki tingkat pengetahuan yang baik mengenai DAS Kampar. Namun, penulis menilai bahwa permasalahan-permasalahan yang diuraikan para pihak belum menyentuh akar permasalahan yang sesungguhnya. Karena persoalan-persoalan tersebut lebih mengarah kepada gejala-gejala yang diakibatkan dari suatu sistem pengelolaan yang bermasalah. Sebagai perbandingan, Latifah (2011) telah melaksanakan kajian yang hampir serupa di sungai Palung, Kabupaten Lombok Timur. Hasil kajian menunjukkan bahwa permasalahan-permasalahan yang mempengaruhi kinerja DAS Palung bukan karena kerusakan vegetasi di wilayah hulu, akan tetapi dikarenakan terbatasnya kegiatan di bidang perekonomian (kurangnya kesempatan kerja dan usaha) yang sangat dipengaruhi oleh tingkat pendidikan masyarakat dan budaya setempat yang belum melihat sumber daya air sebagai sumber daya yang harus dikelola secara bersama dari mulai hulu sampai hilir sehingga memajukan kepentingan individu atau kelompok masih terasa dominan dibandingkan dengan mengedepankan kepentingan bersama.

Walaupun para pihak memiliki tingkat pengetahuan yang baik mengenai DAS Kampar, tetapi masih terdapat perbedaan pandangan mengenai peranan setiap pihak dalam pengelolaan DAS. Padahal menurut (Purwanto et al, 2016), pengelolaan DAS tidak hanya menuntut pemahaman tentang karakteristik DAS, melainkan juga mengenai tentang peranan setiap pihak dalam pengelolaan DAS. Demikian juga pemahaman tentang potensi dan sifat rentan serta kapasitas yang dapat di tenggang oleh suatu DAS terhadap pengelolaan sumber daya alam yang ada.

\section{PENUTUP}

Permasalahan hidrologi yang selama ini sering terjadi menurut masyarakat adalah pencemaran, banjir, erosi, abrasi, kekeruhan, dan pendangkalan. Faktor penyebab permasalahan hidrologi di daerah Riau meliputi 
penggunaan pelet dari keramba jaring apung (KJA), limbah kelapa sawit, dan pembukaan lahan yang masif. Sementara di daerah Sumatera Barat didominasi oleh penebangan liar di bagian hulu dan penambangan batu sungai.

Persepsi umum dari pemerintah menegaskan bahwa dalam beberapa tahun terakhir ini, kualitas air Sungai Kampar semakin memburuk. Hal tersebut disebabkan oleh beberapa hal, meliputi maraknya penebangan hutan, pembangunan yang bersifat parsial dan sektoral, belum tersedianya perencanaan pengembangan sumber-sumber air yang menyeluruh dan terpadu yang mencakup aspek pemanfaatan, pengelolaan, serta pengendalian dan pelestarian.

Secara umum, persepsi para pihak memiliki persamaan, misalnya terdapat persamaan persepsi bahwa tutupan lahan berpengaruh terhadap keberlangsungan DAS Kampar, perambahan hutan menyebabkan terjadinya bukaan lahan yang memicu erosi, sedimentasi, dan banjir. Persepsi yang sama juga terjadi terhadap kualitas air, dimana penurunan kualitas air di DAS Kampar menurut para pihak disebabkan oleh dua faktor utama. Faktor pertama adalah adanya erosi dan sedimentasi yang dihasilkan dari lahan-lahan terbuka di daerah hulu. Faktor kedua adalah adanya pencemaran dari berbagai macam kegiatan di sepanjang sungai dan anak sungai Kampar.

Walaupun begitu, masih terdapat beberapa perbedaan, misalnya terkait dengan program penanaman dan penghijauan yang sudah pernah dilakukan dan diprakarsai oleh pemerintah. Program tersebut menurut masyarakat tidak berjalan dengan baik dan tidak berkelanjutan. Namun, pihak pemerintah menyatakan bahwa program-program ini berhasil dan selalu dilaksanakan secara berkelanjutan.

Dari kesimpulan hasil kajian diatas, dapat disarankan beberapa hal sebagai rekomendasi antara lain:

1. Integrasi antara semua pihak yang terkait dalam tata kelola daerah aliran sungai harus dilakukan secara terpadu dan berkelanjutan;

2. Perlu mendorong adanya kesepakatan bersama para pemangku kepentingan dalam menetapkan prioritas pengelolaan DAS Kampar secara terpadu dan berkelanjutan dan melaksanakannya secara konsisten; dan

3. Perlu mengembangkan skema imbal jasa lingkungan hulu-hilir, yang bisa mengakomodasi keterlibatan semua pihak terkait dalam upaya penyelamatan DAS Upper Kampar secara terpadu dan berkelanjutan.

\section{UCAPAN TERIMA KASIH}

Ucapan terima kasih kepada WWF Indonesia dan semua pihak yang telah membantu penulis dalam melaksanakan kajian dan penulisan artikel ini.

\section{DAFTAR PUSTAKA}

[BPDASHL] Badan Pengelolaan Daerah Aliran Sungai dan Hutan Lindung Indragiri Rokan. (2015). Buku Penyusunan Peta dan Data Informasi Kinerja Daerah Aliran Sungai Kampar Tahun 2015. Pekanbaru.

[KEMENPUPR] Kementerian Pekerjaan Umum dan Perumahan Rakyat. (2015). Pola Pengelolaan Sumber Daya Air Wilayah Sungai Kampar. Jakarta.

[P3ES] Pusat Pengendalian Pembangunan Ekoregion Sumatera. (2014). Kajian Daya Tampung Beban Pencemaran Sungai Kampar. Pekanbaru.

Asnan, G. (2019). Sungai \& Sejarah Sumatera (2nd ed.). Yogyakarta: Penerbit Ombak.

Dhalimi, A. (2006). Permasalahan Gambir (Uncaria Gambir L.) Di Sumatera Barat Dan Alternatif Pemecahannya. Perspektif: Review Penelitian Tanaman Industri, 5(1), 46-59. https://doi.org/10.21082/p.v5n1.2006.\%p

Jia, Y., Liu, X., Zhang, S., Shan, H., \& Zheng, J. (2020). Erosion Survey of the Modern Yellow River Delta BT - Wave-Forced Sediment Erosion and Resuspension in the Yellow River Delta. In Y. Jia, X. Liu, S. Zhang, H. Shan, \& J. Zheng (Eds.) (pp. 65-96). Singapore: Springer Singapore. https://doi.org/10.1007/978981-13-7032-8_3

Latifah, S. (2011). Analisis Akar Masalah Dalam Perencanaan Pengelolaan DAS Terpadu Palung. Wana Tropika, 46 - 60.

Lee, K. E., Abdullah, R., Hanafiah, M. M., Halim, A. A., Mokhtar, M., Goh, C. T., \& Alam, L. (2018). An Integrated 
Approach for Stakeholder Participation in Watershed Management BT Environmental Risk Analysis for AsianOriented, Risk-Based Watershed Management: Japan and Malaysia. In M. Yoneda \& M. Mokhtar (Eds.) (pp. 135143). Singapore: Springer Singapore. https://doi.org/10.1007/978-981-108090-6_10

Miles, J. \& Banyard, P. (2007). Descriptive statistics. In Understanding and using statistics in psychology: A practical introduction: Or, how I came to know and love the standard error (pp. 11-51). London: SAGE Publications Ltd doi: 10.4135/9781446215722.n2

Mulyanto, Parikesit, N. A., \& Utomo, H. (2012). Petunjuk Tindakan dan Sistem Mitigasi Banjir Bandang. Semarang: Kementerian Pekerjaan Umum dan JICA.

Sahin, E. K., Colkesen, I., \& Kavzoglu, T. (2020). A comparative assessment of canonical correlation forest, random forest, rotation forest and logistic regression methods for landslide susceptibility mapping. Geocarto International, 35(4), 341-363. https://doi.org/10.1080/10106049.2018.1 $\underline{516248}$

Thompson, C. B. (2009). Descriptive Data Analysis. Air Medical Journal. https://doi.org/10.1016/j.amj.2008.12.00 1

WWF Indonesia. (2018). Upper Kampar Watershed Revitalization Project. Jakarta.

Yilmaz, I., \& Ercanoglu, M. (2019). Landslide Inventory, Sampling and Effect of Sampling Strategies on Landslide Susceptibility/Hazard Modelling at a Glance BT - Natural Hazards GISBased Spatial Modeling Using Data Mining Techniques. In H. R. Pourghasemi \& M. Rossi (Eds.) (pp. 205-224). Cham: Springer International Publishing. https://doi.org/10.1007/9783-319-73383-8 9

Zevenbergen, C., Gersonius, B., \& Radhakrishan, M. (2020). Flood resilience. Philosophical Transactions of the Royal Society A: Mathematical, Physical and Engineering Sciences, 378(2168), 20190212. https://doi.org/10.1098/rsta.2019.0212 